\title{
3D Conformal Radiotherapy and Cisplatin for Recurrent Malignant Glioma
}

\author{
Lauren VanderSpek, Barbara Fisher, Glenn Bauman, David Macdonald
}

\begin{abstract}
Purpose: To determine the maximum tolerated dose of 3D conformal radiotherapy in combination with Cisplatin for patients with recurrent malignant gliomas. Methods: From 1999-2003, nine patients with recurrent malignant glioma received fractionated radiotherapy and Cisplatin $\left(20 \mathrm{mg} / \mathrm{m}^{2} / \mathrm{d}\right.$ IV on days 1-5) in a Phase I radiation dose escalation trial. Three sequential dose levels were evaluated: $25 \mathrm{~Gy}, 30 \mathrm{~Gy}$, and $35 \mathrm{~Gy}$, using $5 \mathrm{~Gy}$ fractions. All patients received prior external beam radiation (median dose 59.4 (20-60) Gy) and five patients received prior chemotherapy. Results: Six male and three female patients were enrolled with a median age of 52 years, and a median Karnofsky performance status score of 70. The median re-irradiated tumor volume was 18.9 (0.1-78.5) $\mathrm{cm}^{3}$ and the median follow-up was 8.8 (3.2-31.2) months. One patient (30 Gy/ 6 fractions) experienced medically reversible acute grade 3 toxicity. A second patient ( $35 \mathrm{~Gy} / 7$ fractions) experienced acute grade 2 toxicity and histology showed tumor and radiation effect. A third patient ( $25 \mathrm{~Gy} / 5$ fractions) experienced late grade 3 toxicity from radiation necrosis. The radiological responses consisted of complete response (1 patient), partial response (1 patient), and stable disease ( 2 patients). The median overall survival was 8.8 months (95\% CI 8.0-9.9), and the median disease free interval was 2.0 months (95\% CI 1.4-4.4). Seven patients received chemotherapy following re-irradiation and Cisplatin. Conclusion: The maximum tolerated dose of 3D conformal fractionated radiotherapy was $30 \mathrm{~Gy}$ in 6 fractions with low dose Cisplatin, which was well tolerated in terms of acute toxicity for our patient population. This regimen demonstrated only modest efficacy in the treatment of recurrent malignant glioma. Combinations of conformal re-irradiation and other systemic agents may merit investigation. Currently our recommended dose is $30 \mathrm{~Gy}$ in 6 fractions for selected patients.
\end{abstract}

RÉSUMÉ: Radiothérapie conformationnelle 3D et cisplatine dans le traitement de la récidive du gliome malin. But : Il s'agit d'une étude visant à déterminer la dose maximale tolérée de radiothérapie conformationnelle $3 \mathrm{D}$ en combinaison avec l'administration de cisplatine chez les patients qui présentent une récidive de gliome malin. Méthodes : Neuf patients présentant une récidive d'un gliome malin ont reçu de la radiothérapie fractionnée et du cisplatine $(20 \mathrm{mg} / \mathrm{m} 2 / \mathrm{j}$ IV les jours 1 - 5) au cours d'une étude clinique de phase I à dose croissante. Trois niveaux séquentiels de doses ont été évalués : $25 \mathrm{~Gy}, 30 \mathrm{~Gy}$ et $35 \mathrm{~Gy}$, en fractions de $5 \mathrm{~Gy}$. Tous les patients avaient reçu préalablement de la radiothérapie externe (dose médiane 59,4 Gy ; écart de 20 à $60 \mathrm{~Gy}$ ) et cinq patients avaient reçu de la chimiothérapie. Résultats : Six hommes et trois femmes, dont l'âge médian était de 52 ans et le score médian à l'échelle de Karnofsky était de 70, ont été inclus dans l'étude. Le volume médian de la tumeur réirradiée était de $18,9 \mathrm{~cm}(0,1$ à 78,5 $\mathrm{cm}$ ) et la durée médiane du suivi était de 8,8 mois (3,2 à 31,2 mois). Un patient, qui avait reçu 30 Gy/6 fractions, a présenté une toxicité aiguë de grade 3 réversible avec le traitement médical. Un second patient, qui avait reçu $35 \mathrm{~Gy} / 7$ fractions, a présenté une toxicité aiguë de grade 2 et à l'examen anatomopathologique on a constaté des phénomènes reliés à la tumeur et à l'irradiation. Un troisième patient, qui avait reçu $25 \mathrm{~Gy} / 5$ fractions, a présenté une toxicité tardive de grade 3 causée par la nécrose due à l'irradiation. Les réponses radiologiques étaient les suivantes : réponse complète (1 patient), réponse partielle (1 patient) et maladie stable (2 patients). La survie globale médiane était de 8,8 mois (IC de 95\%:8,0 à 9,9), et la survie médiane sans récidive était de 2,0 mois (IC de 95\% : 1,4 à 4,4). Sept patients ont reçu de la chimiothérapie après la réirradiation et du cisplatine. Conclusion : La dose maximale tolérée de radiothérapie conformationnelle 3D était de $30 \mathrm{~Gy}$ en 6 fractions associée à du cisplatine à faible dose. Ce traitement a été bien toléré en ce qui concerne la toxicité aiguë chez nos patients. Ce régime de traitement s'est avéré modestement efficace dans le traitement de la récidive du gliome malin. La combinaison de réirradiation conformationnelle à d'autres agents systémiques mérite d'être étudiée. Nous recommandons actuellement la dose de 30 Gy en 6 fractions chez des patients sélectionnés.

Can. J. Neurol. Sci. 2008; 35: 57-64

Malignant gliomas present therapeutic challenges due to their location, aggressive biologic behavior and diffuse, infiltrative growth. ${ }^{1,2}$ Median survival after initial treatment is approximately 10-15 months for glioblastoma multiforme (GBM), and 40-50 months for anaplastic astrocytoma and anaplastic oligodendrogliomas. ${ }^{1,3}$ Recurrences occur within $2 \mathrm{~cm}$ of the original lesion in approximately $90 \%$ of cases after wholebrain radiation, and up to $100 \%$ of cases after 3 -D conformal
From the Department of Radiation Oncology, London Regional Cancer Program, London Health Sciences Centre, London, Ontario, Canada.

Received February 22, 2007. Final Revisions Submitted October 23, 2007. Reprint requests to: Lauren VanderSpek, Department of Radiation Oncology, London Regional Cancer Program, London Health Sciences Centre, University of Western Ontario, 790 Commissioners Rd. E, London, Ontario, Canada, N6A 4L6 
radiation. $^{4,5}$ At the time of relapse, median survival with supportive care alone is approximately two months. ${ }^{6}$

Treatment options at the time of recurrence include surgery, ${ }^{6-8}$ chemotherapy, ${ }^{9}$ stereotactic radiosurgery (SRS) or 3DCRT, ${ }^{10-12}$ and brachytherapy, ${ }^{7,10,11,13}$ A systematic review of 1415 patients with recurrent high-grade astrocytomas treated with a variety of treatment modalities showed a median survival of 28 weeks with a median time to further progression of 14 weeks. ${ }^{14}$ The rate of radiation necrosis has been reported as high as $20 \%$ for SRS and ranging from $4-40 \%$ for stereotactic radiotherapy (SRT) or 3DCRT. ${ }^{10,11}$

The addition of chemotherapy to radiation treatment of recurrent malignant glioma is another treatment strategy. ${ }^{11,15,16}$ Cisplatin has been evaluated as a radiosensitizer in several tumor types, such as anal, ${ }^{17,18}$ cervical, ${ }^{19-23}$ head and neck, ${ }^{24}$ and bladder $^{25}$ cancers. Weekly Cisplatin with external beam radiotherapy has been shown to be tolerated for treatment of malignant brain tumors. ${ }^{15,26}$ Cisplatin at a dose of $20 \mathrm{mg} / \mathrm{m}^{2} /$ day $\mathrm{x} 5$ days together with $\mathrm{I}^{125}$ implants also has acceptable toxicity. ${ }^{27}$ For the current study, a dose of Cisplatin $20 \mathrm{mg} / \mathrm{m}^{2} /$ day IV on days 1-5 of radiation was chosen based on these demonstrated tolerances in the literature.

To determine the maximum tolerated dose of radiation when in combination with Cisplatin for treatment of recurrent malignant glioma, a dose escalation schedule for this study was based on Shepherd et al who treated 29 patients with high-grade glioma to doses ranging from 20-50 Gy in 5 Gy/fraction. ${ }^{28} \mathrm{~A}$ total dose of $>40$ Gy was found to be a major predictor of radiation damage $(\mathrm{p}<0.005)$. In the current study three sequential dose levels were evaluated: $25 \mathrm{~Gy}, 30 \mathrm{~Gy}$, and $35 \mathrm{~Gy}$, using 5 Gy per fraction.

\section{Methods}

\section{Patient and tumor characteristics}

From March 1999 to June 2003, nine patients with recurrent malignant glioma received fractionated radiotherapy and lowdose Cisplatin in an Institutional Review Board approved Phase I radiation dose escalation trial at the London Regional Cancer Program. Tumor progression following initial treatment was documented by imaging characteristics in all cases and also with histology in three patients. The patient and tumor characteristics are shown in Table 1.

The most recent histology prior to re-irradiation was as follows: GBM (six patients), AA (one patient), and mixed anaplastic glioma (two patients). Initial surgery consisted of partial resection (two patients) and gross total resection (six patients), and one patient had a biopsy at recurrence. Multiple resections were performed in three patients. All patients previously received fractionated external beam radiation with a median dose of 59.4 Gy (range 20-60 Gy). The median interval from completion of initial radiotherapy to the start of reirradiation was nine months (range 2-93 months). Five patients received prior chemotherapy: PCV (Procarbazine, Lomustine, Vincristine) (two patients), modified PCV (one patient), Temozlomide (two patients), Topotecan (one patient), SU101 (one patient) and Marimastat (one patient).

Patients were enrolled on the study if they had histological confirmation of malignant glioma and radiological (CT/MRI)

\section{Table 1: Clinical characteristics of nine patients treated with 3D conformal radiotherapy and low dose Cisplatin for recurrent malignant glioma}

\begin{tabular}{llc}
\hline Characteristic & & (n) \\
Age (y) & Median (range) & $52(24-75)$ \\
Gender & Male/Female & $6 / 3$ \\
Performance Status (KPS) & Median (range) & $70(70-100)$ \\
Neurologic Function Status (NF) & Median (range) & $1(0-2)$ \\
Histology & GBM & 6 \\
& Mixed anaplastic glioma & 2 \\
Treatments prior to relapse & AA & 1 \\
& RT & 1 \\
Surgery at relapse & Surgery + RT & 3 \\
Interval between courses of RT (mo) & Surgery + RT +CT & 5 \\
Tumor volume $\left(\mathrm{cm}^{3}\right)$ & Median (range) & $1 / 1 / 1$ \\
Site & Median (range) & $9(2-93)$ \\
& Frontal & $19(0.1-79)$ \\
& Frontal/Temporal & 1 \\
& Frontal/Corpus Callosum & 2 \\
& Temporal & 1 \\
& Parietal & 2 \\
& Parietal/Occipital & 1 \\
& & 2 \\
\hline
\end{tabular}

* a fourth patient underwent Ommaya Reservoir insertion, without resection. KPS (Karnofsky Performance Status, NF (Neurologic Function), GBM (glioblastoma multiforme), AA (anaplastic astrocytoma), Bx (biopsy)

evidence of recurrence/progression and met the following additional criteria: (1) Karnofsky Performance Score (KPS) $\geq$ 50; (2) neurological function status $0-3$; (3) no cytotoxic chemotherapy $<1$ month prior to protocol therapy; (4) age $\geq 18$ years; (5) absolute neutrophils $\geq 1500 / \mathrm{mm}^{3}$, platelets $\geq$ $100,000 / \mathrm{mm}^{3}, \mathrm{BUN} \leq 30 \mathrm{mg}$, creatinine $\leq 1.8 \mathrm{mg}$, bilirubin $\leq 2$ $\mathrm{mg}$, serum glutamate pyruvate transaminase (SGPT) or serum glutamic-oxaloacetic transaminase $(\mathrm{SGOT}) \leq 2 \mathrm{x}$ upper limit of normal (ULN); (6) prior external beam radiation $\geq 2$ months prior to re-treatment; and (7) recurrent tumor diameter $<6 \mathrm{~cm}$. Patients with brainstem tumors (midbrain, pons, medulla), multiple intracranial lesions, no measurable tumor, leptomeningeal metastases or subependymal spread were excluded.

\section{Study endpoints}

Central nervous system (CNS) toxicity was defined as the development of any new treatment-related neurological symptoms or signs ( $\pm \mathrm{CT}$ and/or MRI abnormalities) following the radiation treatment that were felt attributable to the treatment. Toxicities were scored according to the Radiation Therapy Oncology Group (RTOG) CNS toxicity subscale. ${ }^{29}$ For each dose level, an observed rate of $>25 \%$ grade $\geq 3$ acute, medically irreversible, CNS toxicity was considered unacceptable and would result in suspension of accrual and the previous dose would be accepted as the maximally tolerated dose. Acute toxicity was within 90 days from the start of re-irradiation.

Radiological response was defined by the Macdonald criteria: ${ }^{30}$ complete response was disappearance of all clinical 
evidence of tumor, determined by two observations $\geq 4$ weeks; partial response was $\geq 50 \%$ reduction in the volume of the lesions for $\geq 4$ weeks duration; stable disease was response < $50 \%$ or progression $<25 \%$ for $\geq 4$ weeks duration; progressive disease was unequivocal increase in the volume of the tumor of $\geq 25 \%$. Clinical response consisted of either an objective improvement in neurological status or no neurological deterioration with a stable or decreasing steroid dose. There must also have been stable or regressing tumor on imaging.

Survival was determined from the start of re-irradiation to the date of death. Progression free interval was also determined from the start of re-irradiation to the time of clinical recurrence. Survival curves were calculated by the method of Kaplan and Meier. ${ }^{31}$

All patients registered for the study were included in the analysis, with none being lost to follow-up. No patient died or withdrew from the study prior to treatment completion.

\section{Treatment planning and delivery}

Informed written consent was obtained from all study patients. Each patient was positioned and immobilized with an individualized thermoplastic mask with treatment planning CT slices $\leq 0.5 \mathrm{~cm}$ through the regions of interest. Gross tumor (GTV), clinical (CTV), and planning (PTV) target volumes were defined based on the treatment planning $\mathrm{CT}$, with registration to
MRI when possible, in accordance with the 1993 International Commission on Radiation Units and Measurements (ICRU) ${ }^{32}$

Treatment was delivered to the PTV by fields determined by 3-D planning to produce the optimal conformal plan. The use of beam intensity modulation was not allowed (except for wedges, compensating filters, and static beam shaping devices such as multileaf collimators [MLC]).

Treatment was delivered using daily fractions of $5 \mathrm{~Gy}$ for all patients. Three sequential dose levels were evaluated: $25 \mathrm{~Gy}$ (four patients), $30 \mathrm{~Gy}$ (three patients), and $35 \mathrm{~Gy}$ (two patients). Treatment details are shown in Table 2.

Cisplatin was administered as an intravenous infusion over $30-40$ minutes at a dose of $20 \mathrm{mg} / \mathrm{m}^{2}$ daily on radiation treatment days $1-5$. The average time between chemotherapy and radiation was 56 minutes (range 10 minutes to 2 hours and 45 minutes), though data was incomplete for three patients. There was no dose escalation of Cisplatin. None of the patients required dose modification, which was based on absolute neutrophil count, and all patients received the full course of Cisplatin.

\section{RESULTS}

\section{Acute Toxicity}

All patients received the scheduled treatment except one patient without toxicity who declined the final of six fractions.

Table 2: Treatment parameters and outcome

\begin{tabular}{|c|c|c|c|c|c|c|c|c|}
\hline Patient & KPS & NF & Treatment prior to relapse & $\begin{array}{l}\text { Surgery at } \\
\text { relapse }\end{array}$ & Reirradiation schedule & Treatment post study & $\begin{array}{l}\text { PFI } \\
(\mathrm{mo})\end{array}$ & $\begin{array}{l}\text { OS } \\
(\mathbf{m o})\end{array}$ \\
\hline 1 & 80 & 1 & $\begin{array}{l}\text { Total resection } \\
\text { RT ( } 60 \mathrm{~Gy} / 30 \text { fractions) } \\
\text { Topotecan, SU101 }\end{array}$ & Partial resection & $25 \mathrm{~Gy} / 5$ fractions & PCV, Temozolomide & 0.8 & 8.6 \\
\hline 2 & 80 & 2 & $\begin{array}{l}\text { Total resection } \\
\text { RT ( } 60 \mathrm{~Gy} / 30 \text { fractions) } \\
\text { Marimastat }\end{array}$ & No & 25 Gy/ 5 fractions & $\mathrm{PCV}$ & 1.4 & 8.8 \\
\hline 3 & 70 & 2 & $\begin{array}{l}\text { Total resection (x 2) } \\
\text { RT }(59.4 \text { Gy/ } 33 \text { fractions) } \\
\text { Modified PCV }\end{array}$ & No & 25 Gy/ 5 fractions & Partial resection & $31.2 *$ & 31.2 \\
\hline 4 & 70 & 1 & $\begin{array}{l}\text { RT ( } 20 \text { Gy/ } 5 \text { fractions, whole } \\
\text { brain) }\end{array}$ & Biopsy & $25 \mathrm{~Gy} / 5$ fractions & Lomustine & 1.3 & 8.0 \\
\hline 5 & 70 & 1 & $\begin{array}{l}\text { Total resection } \\
\text { RT ( } 60 \text { Gy/ } 30 \text { fractions })\end{array}$ & No & $30 \mathrm{~Gy} / 6$ fractions & Lomustine & 4.7 & 9.9 \\
\hline 6 & 70 & 2 & $\begin{array}{l}\text { Partial resection (x 3) } \\
\text { RT ( } 54 \text { Gy/ } 30 \text { fractions) } \\
\text { PCV, Temozolomide }\end{array}$ & $\begin{array}{l}\text { Ommaya } \\
\text { reservoir } \\
\text { insertion }\end{array}$ & $30 \mathrm{~Gy} / 6$ fractions & Etoposide & 1.7 & 3.2 \\
\hline 7 & 80 & 1 & $\begin{array}{l}\text { Total resection } \\
\text { RT ( } 60 \text { Gy/ } 30 \text { fractions })\end{array}$ & No & $30 \mathrm{~Gy} / 6$ fractions & Temozolomide, Etoposide & 2.1 & 9.7 \\
\hline 8 & 100 & 0 & $\begin{array}{l}\text { Partial resection (x 2) } \\
\text { RT ( } 54 \text { Gy/ } 30 \text { fractions) } \\
\text { PCV, Temozolomide }\end{array}$ & Total resection & 35 Gy/ 7 fractions & $\begin{array}{l}\text { Partial resection } \\
\text { Etoposide, Tamoxifen }\end{array}$ & 2.0 & 14.1 \\
\hline 9 & 70 & 2 & $\begin{array}{l}\text { Total resection } \\
\text { RT }(60 \mathrm{~Gy} / 30 \text { fractions })\end{array}$ & No & 35 Gy/ 7 fractions & No & 4.4 & 5.0 \\
\hline
\end{tabular}

* this patient had radionecrosis and no objective relapse. KPS (Karnofsky Performance Status), NF (Neurologic Function), RT (radiation therapy), PCV (Procarbazine, Lomustine, Vincristine), PFI (progression free interval), OS (overall survival), MO (months) 
This patient was replaced at the $30 \mathrm{~Gy}$ level. One patient treated with 30 Gy in six fractions experienced acute grade 3 toxicity with decreased level of consciousness six days after the first reirradiation fraction. The patient had an Ommaya reservoir that required drainage prior to and during treatment, which improved her level of consciousness. One patient treated with $35 \mathrm{~Gy}$ in seven fractions had acute grade 2 toxicity at 60 days after the first re-irradiation fraction (word-finding difficulties and slurred speech). This patient underwent partial resection and tumor as well as radiation effect was seen on histology. The study was terminated at the $35 \mathrm{~Gy}$ level due to the radiation effect seen on histology.

\section{Late Toxicity}

A patient who received 25 Gy in five fractions experienced grade 3 confusion and weakness with falls on day 21 after the initial re-irradiation fraction. Increased steroid initially stabilized the patient's neurological function. Surgery was performed 7.4 months after the initial re-irradiation fraction and radiation induced necrosis with scant residual treated glioma was reported. This patient survived 31 months from the start of re-irradiation with no equivocal tumor recurrence.

\section{Response}

Radiological response according to the Macdonald ${ }^{30}$ criteria consisted of complete response (one patient), partial response (one patient), stable disease (two patients) and progression (five patients). The patient with the complete response developed late radiation necrosis. The patient with the partial response on imaging was clinically worsened due to the steroid itself. The clinical response for the two patients with stable disease on imaging consisted of neurological improvement in one patient

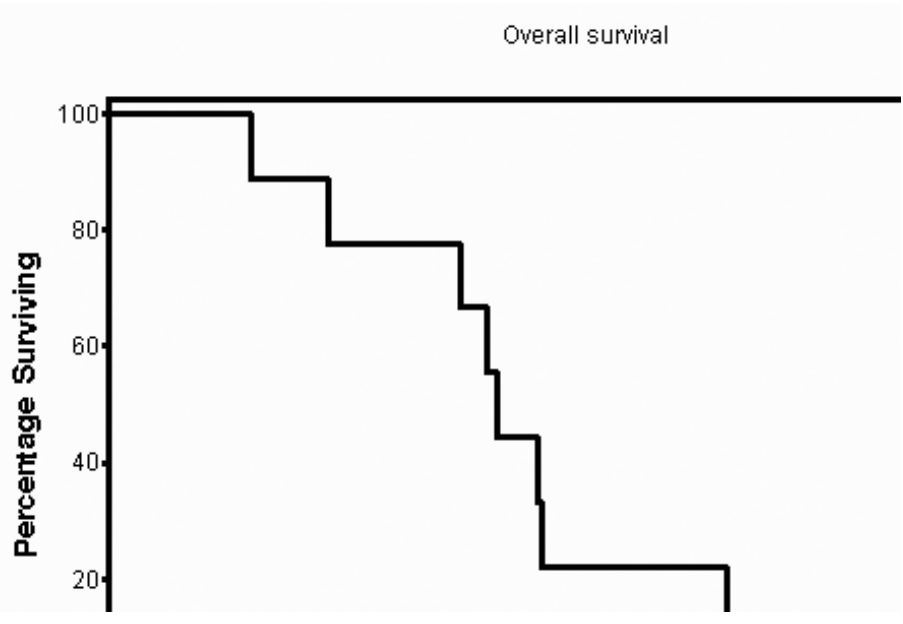

Figure 1: Overall survival in months for patients treated with $3 D$ conformal radiotherapy and low dose Cisplatin for recurrent malignant glioma. The percentage survival does not reach zero on this time scale as one patient survived for 31.2 months with a diagnosis of late radiation necrosis and no equivocal tumor recurrence after $3 D$ conformal radiotherapy and low dose Cisplatin. for four months with no steroid prescribed, and stable neurological symptoms with decreased steroid requirement for three months, respectively.

The median follow-up was 8.8 months (3.2-31.2) from the start of re-irradiation. The median overall survival was 8.8 months (95\% CI 8.0-9.9) (Figure 1), and the median disease free interval was 2.0 months (95\% CI 1.4-4.4) (Figure 2). All patients were deceased at the time of analysis.

\section{Additional therapy}

Seven patients were treated with further chemotherapy consisting of PCV (two patients), single agent Lomustine (two patients), Etoposide (three patients), Temozolomide (two patients), and Tamoxifen (one patient).

\section{Discussion}

Recurrent malignant gliomas continue to have a poor prognosis with modest response to various surgical and radiation techniques. ${ }^{6-8,10,11,13}$ Dose escalation studies for initial radiation have shown no significant increase in morbidity with conformal fields up to doses of $>70 \mathrm{~Gy}^{33,34}$ but series evaluating escalating doses up to 80-90 Gy in limited volumes have not improved local control. $^{34}$ The treatment strategy in this study was to add low dose Cisplatin $\left(20 \mathrm{mg} / \mathrm{m}^{2}\right)$ IV daily on re-irradiation treatment days 1-5 to a dose escalation regimen based on the dose escalation study by Shepherd et al. ${ }^{28}$ The addition of chemotherapy to radiation for the treatment of recurrent malignant glioma has been described in the literature for several chemotherapeutic agents (Table 3). ${ }^{15,16,35-38}$

In the Shepherd study, a total dose of $>40$ Gy was a significant predictor of radiation damage. The median survival was 11 months for 32 patients with recurrent high-grade glioma (including three patients with high grade oligodendroglioma)

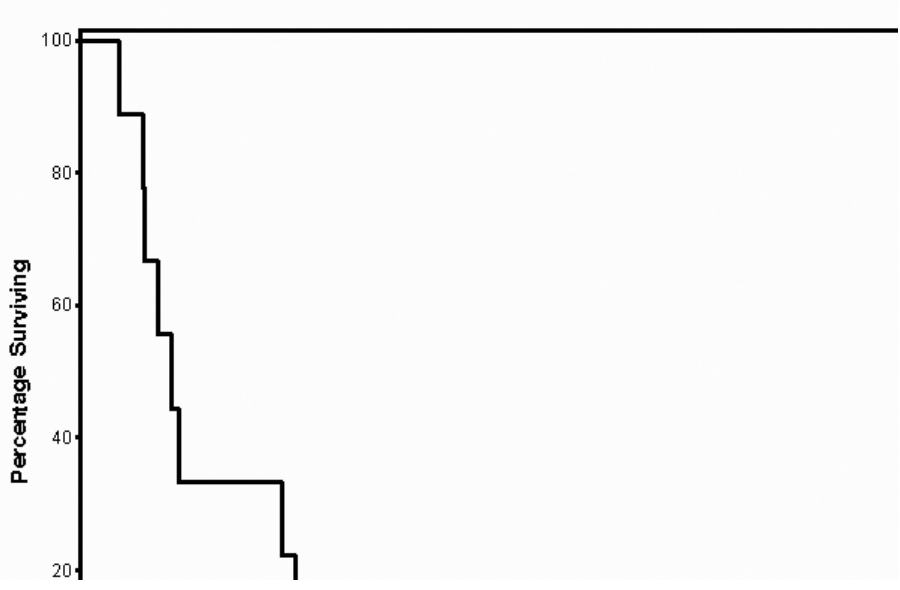

Figure 2: Disease free interval in months for patients treated with $3 D$ conformal radiotherapy and low dose Cisplatin for recurrent malignant glioma. The percentage survival does not reach zero on this time scale as one patient survived for 31.2 months with a diagnosis of late radiation necrosis and no equivocal tumor recurrence after $3 D$ conformal radiotherapy and low dose Cisplatin. 
Table 3: Re-irradiation with chemotherapy series

\begin{tabular}{|c|c|c|c|c|c|c|c|}
\hline Author & $\mathbf{n}$ & Histology (n) & $\begin{array}{c}\text { Median } \\
\text { Radiation } \\
\text { Dose and } \\
\text { Schedule }\end{array}$ & Chemotherapy & $\begin{array}{l}\text { Median } \\
\text { Survival } \\
\text { (months) }\end{array}$ & $\begin{array}{l}\text { Progression- } \\
\text { Free Survival } \\
\quad \text { (months) }\end{array}$ & $\begin{array}{l}\text { Graded Toxicity / } \\
\text { Radiation Necrosis (n) }\end{array}$ \\
\hline Arcicasa $^{23}$ & 24 & High-grade glioma (24) & $\begin{array}{l}34.5 \mathrm{~Gy} / \\
1.5 \mathrm{~Gy} \text { per } \\
\text { day/ } 5 \text { days } \\
\text { per week }\end{array}$ & Lomustine & 13.7 & 8.4 & $\begin{array}{l}\text { G4 thrombocytopenia (1) } \\
\text { G3 leucopenia (3) }\end{array}$ \\
\hline Larson $^{42}$ & 26 & $\begin{array}{l}\text { GBM (14) } \\
\text { AA (8) } \\
\text { AO (1) } \\
\text { Mixed malignant glioma (3) }\end{array}$ & $\begin{array}{l}16.5 \mathrm{~Gy} \text { to } \\
\text { the } \\
\text { prescription } \\
\text { isodose }\end{array}$ & Marimastat & $\begin{array}{l}17(\text { grade } 3) \\
9.5(\text { grade } 4)\end{array}$ & $\begin{array}{l}7.8(\text { grade } 3) \\
3.8(\text { grade } 4)\end{array}$ & $\begin{array}{l}\text { G3 MSK (2) } \\
\text { No firm conclusion } \\
\text { regarding radiation } \\
\text { necrosis }\end{array}$ \\
\hline Glass $^{22}$ & 20 & $\begin{array}{l}\text { Malignant astrocytoma: } \\
\text { Grade } 3(7) \\
\text { Grade } 4(13)\end{array}$ & $\begin{array}{l}42 \text { Gy/ } 6 \\
\text { Gy once- } \\
\text { twice per } \\
\text { week }\end{array}$ & Cisplatin & 13.8 & 4.6 & $\begin{array}{l}\text { G3 thrombocytopenia (4) } \\
\text { G3-4 leukopenia (3) } \\
\text { Radiation necrosis (3) }\end{array}$ \\
\hline Lederman $^{43}$ & 88 & GBM & $\begin{array}{l}24 \text { Gy/ } 6 \\
\text { Gy per } \\
\text { week x } 4\end{array}$ & Paclitaxel & 7.0 & Not reported & Radiation necrosis (7) \\
\hline Schafer $^{44}$ & 14 & $\begin{array}{l}\text { GBM (5) } \\
\text { AA }(7) \\
\text { High-grade } \\
\text { oligodendroglioma (2) }\end{array}$ & $\begin{array}{l}30 \mathrm{~Gy} / 2 \\
\text { Gy per day/ } \\
5 \text { days per } \\
\text { week }\end{array}$ & Temozolomide & 7.5 & 5.0 & $\begin{array}{l}\text { Mental degradation (1) } \\
\text { Severe cephalgia (1) } \\
\text { No late toxicities reported }\end{array}$ \\
\hline Schonekaes $^{45}$ & 25 & High-grade glioma (25) & $\begin{array}{l}20-30 \mathrm{~Gy} \\
(2 \times 1.2 \mathrm{~Gy} \\
\text { per day) }\end{array}$ & Temozolomide & 9.3 & 7.0 & No G3-4 toxicity \\
\hline Current Study & 9 & $\begin{array}{l}\text { GBM (6) } \\
\text { AA (1) } \\
\text { Mixed anaplastic glioma (2) }\end{array}$ & $\begin{array}{l}30 \text { Gy/ } 5 \\
\text { Gy per day/ } \\
5 \text { days per } \\
\text { week }\end{array}$ & Cisplatin & 8.8 & 2.0 & $\begin{array}{l}\text { G3 CNS toxicity }(2) \\
\text { (One patient had radiation } \\
\text { necrosis) }\end{array}$ \\
\hline
\end{tabular}

GBM (glioblastoma multiforme), AA (anaplastic astrocytoma), AO (anaplastic oligodendroglioma), G3 (grade 3 toxicity), G4 (grade 4 toxicity), MSK (musculoskeletal), CNS (central nervous system)

treated with SRT. Our study showed a maximum tolerated dose of $30 \mathrm{~Gy}$ in six fractions in combination with low dose Cisplatin with acceptable acute toxicity, but with an inferior median survival of 8.8 months. The patient population in our study had a lower median KPS, higher median patient age, and a shorter interval from prior radiation to re-irradiation.

Laing reported the results of a phase I/II study of SRT for recurrent glioma with a dose escalation between $30-50$ Gy in 5 Gy/fraction. Suggestive of a relation between toxicity and tumor dose, 5 of 14 patients treated with doses $\geq 40$ Gy developed radiation toxicity versus none of the eight patients treated with doses $\leq 35$ Gy. The median survival was 9.8 months and at six months $67 \%$ of patients were functionally unchanged or improved. ${ }^{39}$ The median tumor volume was $25 \mathrm{~cm}^{3}$ (range 1-93 $\mathrm{cm}^{3}$ ) with diameters ranging in size from $1.4-7.0 \mathrm{~cm}$.

The study of hypofractionated SRT for recurrent malignant glioma by Ernst-Stecken et $\mathrm{al}^{12}$ used a treatment regimen of $5 \mathrm{x}$ 7 Gy three times a week up to a total dose of 35 Gy. Median overall survival was 12 months. Quality of life scores were kept stable in two thirds of patients for a median of nine months. In four patients with an increase in edema and steroid requirement, and no increase in GTV, the median re-irradiated volumes with a dose above 3, 4, and 5 Gy per fraction were higher than in those without toxicity. ${ }^{12}$
As pointed out by Ernst-Stecken et al, ${ }^{12}$ reliable data on the effects of hypofractionated SRT for recurrent glioma on both tumor and normal tissue is limited, ${ }^{11,15,28,36,40-42}$ whereas in SRS the tolerance doses have been described. ${ }^{43}$ For larger volume recurrences, hypofractionated SRT may result in higher efficacy than standard fractionation by the use of relatively high single doses. ${ }^{16}$ SRT has also been shown to have a lower risk of late complications as compared to SRS. ${ }^{12,44}$

Late effects from radiation therapy correlate with cumulative radiation dose, fractionation, treatment volume, patient age, and use of chemotherapy., 76,45 For conventional fractionated radiotherapy, the radiation dose associated with a $5 \%$ probability of radiation necrosis (TD5) is estimated to be between 45-60 Gy. ${ }^{46-48}$ There is no concise data on recovery of normal brain tissue after radiation, however, it has been suggested that there is a 'remembrance' of approximately $50 \%$ of the dose by 1-2 years after the original radiation. ${ }^{47,49}$ In regard to SRS, there is an inverse relationship between the volume irradiated and the total radiation dose such that as the volume of irradiated tissue increases, the dose that results in radiation necrosis decreases. ${ }^{50}$ In clinical practice, this inverse relationship may not be apparent because of the concern of late effects may prompt physicians to decrease dose and/or volumes to avoid complications. Radiation Therapy Oncology Group 94-11 tested the hypothesis that 
radiation therapy of smaller volumes would allow the safe administration of higher doses of radiation compared to patients with large volumes of tumor. ${ }^{51}$ There was a trend toward increased survival with higher radiation dose in recursive partitioning analysis Class III/IV patients, but this may be due to smaller tumor sizes in that arm of the trial. Retrospective data shows better outcomes with smaller tumors post surgery ${ }^{28,52}$ and similarly, tumors $\leq 4 \mathrm{~cm}$ that are eligible for SRS have a better prognosis..$^{28,53}$ Lead-time and length bias are also issues with smaller tumors. ${ }^{28}$ In our study tumors greater than $6 \mathrm{~cm}$ were excluded to minimize potential late toxicity and this may have influenced the modest effect of the treatment.

For newly diagnosed GBM the standard of care is concurrent radiation with oral Temozolomide followed by adjuvant Temozolomide. ${ }^{10,54-56}$ For recurrent malignant glioma, however, there is no consensus regarding salvage chemotherapy. ${ }^{10}$

Cisplatin increases the slope of radiation dose-response curves in mammalian cells in vitro and inhibits repair of sublethal radiation damage ${ }^{57}$ and enhances radiation effect in vivo ${ }^{57-60}$ Cisplatin has also been shown to radiosensitive human glioma cell lines with a dose-modifying factor of 1.2-1.7. ${ }^{61}$ Penetration of Cisplatin through the blood-brain barrier is limited due to the size of the molecule. ${ }^{62}$ Thompson found that the concentration of Cisplatin was $0.17 \mu \mathrm{g} / \mathrm{kg}$ in brain tissue in three patients who received Cisplatin $50 \mathrm{mg} / \mathrm{m}^{2}$ monthly, which is felt by Sheleg ${ }^{62}$ to be insufficient for achieving an antitumor effect. ${ }^{63}$ Other authors argue that concentrations of Cisplatin as low as $1 \mu \mathrm{g} / \mathrm{ml}$ are radiopotentiating and that intracerebral concentrations of platinum in this range are attained with doses of 20 to $25 \mathrm{mg} / \mathrm{m}^{2}{ }^{64}$ Following intravenous administration of Cisplatin, Stewart found low concentrations of platinum in normal brain parenchyma, but high concentrations in intracerebral tumor and the surrounding edema. This difference was attributed to disruption of the blood-brain barrier within the tumor vasculature. ${ }^{64}$ In the current study, Cisplatin did not appear to provide significant radiosensitization. Glass demonstrated similar results with weekly Cisplatin $\left(40 \mathrm{mg} / \mathrm{m}^{2}\right)$ and external beam radiotherapy for the treatment of malignant brain tumors in a study of 20 patients with recurrent, progressive or persistent malignant astrocytoma, with SRT once or twice weekly. ${ }^{15}$ There was manageable acute toxicity and one patient had a partial response, eleven had stable disease, and eight patients progressed. Surgery was required in five patients for either tumor progression or radiation necrosis. Median survival for all patients was 55 weeks and the median response duration was 18.5 weeks. Median survival was 8.5 months for a subgroup with an interval of ten weeks or more between initial EBRT and SRT, whereas median survival for a subgroup treated at less than a ten week interval for progression or potential for tumor progression based on SPECT imaging was 16.6 months.

Investigation into combinations of other systemic agents with conformal re-irradiation may be merited. Targeted therapies currently under investigation for recurrent high-grade gliomas may also merit investigation in the future in combination with radiotherapy. For example, the epidermal growth factor receptor (EGFR) inhibitor, Gefitinib (ZD1839 or Iressa), has demonstrated a median survival for patients with recurrent GBM or 39.4 weeks after first relapse. ${ }^{10,65}$ Thalidomide was well tolerated and median survival was 28 weeks in a phase II study for patients with recurrent high-grade glioma. ${ }^{10,66}$ Alternate forms of delivery of chemotherapy, such as the placement of Gliadel Wafers (MCI Pharma Inc, Bloomington, MN), ${ }^{10,67}$ may also provide novel approaches to treatment in combination with radiation.

The maximum tolerated dose of 3D conformal fractionated radiotherapy was 30 Gy in six fractions with low dose Cisplatin, which was well tolerated in terms of acute toxicity for our patient population. There is a risk of late radiation necrosis in long-term survivors and the rate of radiation necrosis in this study is comparable to other salvage regimens in the literature. The regimen demonstrated only modest efficacy in the treatment of recurrent malignant glioma. Currently at our centre re-irradiation is offered to patients with a good performance status, a long interval from previous radiation, for which surgery is not an option, and chemotherapy or a clinical trial have been refused or are unavailable. The recommended dose is $30 \mathrm{~Gy}$ in six fractions. Combinations of conformal re-irradiation and other systemic agents may merit investigation.

\section{ACKNOWLEDGEMENT}

The authors thank Frances Whiston for all of her work with the statistics.

\section{REFERENCES}

1. Grosu AL, Weber WA, Franz M, Stark S, Piert M, Thamm R, et al. Reirradiation of recurrent high-grade gliomas using amino acid PET (SPECT)/CT/MRI image fusion to determine gross tumor volume for stereotactic fractionated radiotherapy. Int J Radiat Oncol Biol Phys. 2005;63:511-9.

2. Nieder C, Grosu AL, Mehta MP, Andratschke N, Molls M. Treatment of malignant gliomas: radiotherapy, chemotherapy and integration of new targeted agents. Expert Rev Neurother. 2004;4:691-703.

3. Gaspar LE, Fisher BJ, Macdonald DR, LeBer DV, Halperin EC, Schold SC, Jr., et al. Supratentorial malignant glioma: patterns of recurrence and implications for external beam local treatment. Int J Radiat Oncol Biol Phys. 1992;24:55-7.

4. Hochberg FH, Pruitt A. Assumptions in the radiotherapy of glioblastoma. Neurology. 1980;30:907-11.

5. Lee SW, Fraass BA, Marsh LH, Herbort K, Gebarski SS, Martel MK, et al. Patterns of failure following high-dose 3-D conformal radiotherapy for high-grade astrocytomas: a quantitative dosimetric study. Int J Radiat Oncol Biol Phys. 1999;43:79-88.

6. Guyotat J, Signorelli F, Frappaz D, Madarassy G, Ricci AC, Bret P. Is reoperation for recurrence of glioblastoma justified? Oncol Rep. 2000; 7:899-904.

7. Bauman GS, Sneed PK, Wara WM, Stalpers LJ, Chang SM, McDermott MW, et al. Reirradiation of primary CNS tumors. Int J Radiat Oncol Biol Phys. 1996;36:433-41.

8. Brandes A, Vastola F, Monfardini S. Reoperation in recurrent highgrade gliomas: literature review of prognostic factors and outcome. Am J Clin Oncol. 1999;22:387-90.

9. Stupp R, Hegi $M$, van den Bent M, Mason W, Weller M, Mirimanoff R, et al. Changing paradigms - an update on the multidisciplinary management of malignant glioma. Oncologist. 2006;11:165-80.

10. Butowski N, Sneed P, Chang S. Diagnosis and treatment of recurrent high-grade astrocytoma. J Clin Oncol. 2006;24: 1273-80.

11. Voynov G, Kaufman S, Hong T, Pinkerton A, Simon R, Dowsett R. Treatment of recurrent malignant gliomas with stereotactic intensity modulated radiation therapy. Am J Clin Oncol. 2002;25:606-11. 
12. Ernst-Stecken A, Ganslandt O, Lambrecht U, Sauer R, Grabenbauer G. Survival and quality of life after hypofractionated stereotactic radiotherapy for recurrent malignant glioma. J Neurooncol. 2007;81(3):287-94.

13. Gutin P, Leibel S, Wara W, Choucair A, Levin V, Philips T, et al. Recurrent malignant gliomas: survival following interstitial brachytherapy with high-activity iodine-125 sources. J Neurosurg. 1987;67:864-73.

14. Huncharek M, Muscat J. Treatment of recurrent high grade astrocytoma; results of a systematic review of 1,415 patients. Anticancer Res. 1998;18:1303-11.

15. Glass J, Silverman C, Axelrod R, Corn B, Andrews D. Fractionated stereotactic radiotherapy with cis-platinum radiosensitization in the treatment of recurrent, progressive, or persistent malignant astrocytoma. Am J Clin Oncol. 1997;20:226-9.

16. Arcicasa M, Roncadin M, Bidoli E, Dedkov A, Gigante M, Trovo M. Reirradiation and lomustine in patients with relapsed highgrade gliomas. Int J Radiat Oncol Biol Phys. 1999;43:789-93.

17. Peiffert D. Rationale and progress of the phase III trial: intensification of the treatment of locally advanced squamous cell carcinoma of the anal canal. Cancer Radiother. 2003;7Suppl $1: 100-7$.

18. Flam M, John M, Pajak TF, Petrelli N, Myerson R, Doggett S, et al. Role of mitomycin in combination with fluorouracil and radiotherapy, and of salvage chemoradiation in the definitive nonsurgical treatment of epidermoid carcinoma of the anal canal: results of a phase III randomized intergroup study. J Clin Oncol. 1996;14:2527-39.

19. Keys HM, Bundy BN, Stehman FB, Muderspach LI, Chafe WE, Suggs CL, III, et al. Cisplatin, radiation, and adjuvant hysterectomy compared with radiation and adjuvant hysterectomy for bulky stage IB cervical carcinoma. N Engl J Med. 1999;340:1154-61.

20. Peters WA, III, Liu PY, Barrett RJ, Stock RJ, Monk BJ, Berek JS, et al. Concurrent chemotherapy and pelvic radiation therapy compared with pelvic radiation therapy alone as adjuvant therapy after radical surgery in high-risk early-stage cancer of the cervix. J Clin Oncol. 2000;18:1606-13.

21. Rose PG, Bundy BN, Watkins EB, Thigpen JT, Deppe G, Maiman MA, et al. Concurrent cisplatin-based radiotherapy and chemotherapy for locally advanced cervical cancer. N Engl J Med. 1999;340:1144-53.

22. Eifel PJ, Winter K, Morris M, Levenback C, Grigsby PW, Cooper $\mathrm{J}$, et al. Pelvic irradiation with concurrent chemotherapy versus pelvic and para-aortic irradiation for high-risk cervical cancer: an update of radiation therapy oncology group trial (RTOG) 9001. J Clin Oncol. 2004;22:872-80.

23. Whitney CW, Sause W, Bundy BN, Malfetano JH, Hannigan EV, Fowler WC, Jr., et al. Randomized comparison of fluorouracil plus cisplatin versus hydroxyurea as an adjunct to radiation therapy in stage IIB-IVA carcinoma of the cervix with negative para-aortic lymph nodes: a Gynecologic Oncology Group and Southwest Oncology Group study. J Clin Oncol. 1999;17: 1339-48

24. Sharma VM, Wilson WR. Radiosensitization of advanced squamous cell carcinoma of the head and neck with cisplatin during concomitant radiation therapy. Eur Arch Otorhinolaryngol. 1999;256:462-5.

25. Sauer R, Dunst J, Altendorf-Hofmann A, Fischer H, Bornhof C, Schrott KM. Radiotherapy with and without cisplatin in bladder cancer. Int J Radiat Oncol Biol Phys. 1990;19:687-91.

26. Stewart D, Leavens M, Maor M, Feun L, Luna M, Bonura J, et al. Human central nervous system distribution of cisdiamminedichloroplatinum and use as a radiosensitizer in malignant brain tumors. Cancer Res. 1982;42:2474-9.

27. Chamberlain M, Barba D, Komanik P, Benson A, Saunders W, Shea M. Toxicity and safety study of concurrent cisplatin and I125 brachytherapy. Arch Neurol. 1995;52:162-7.

28. Shepherd S, Laing R, Cosgrove V, Warrington A, Hines F, Ashley $S$, et al. Hypofractionated stereotactic radiotherapy in the management of recurrent glioma. Int J Radiat Oncol Biol Phys. $1997 ; 37: 393-8$
29. Shaw E, Scott C, Souhami L, Dinapoli R, Kline R, Loeffler J, et al. Single dose radiosurgical treatment of recurrent previously irradiated primary brain tumors and brain metastases: final report of RTOG protocol 90-05. Int J Radiat Oncol Biol Phys. 2000; 47:291-8.

30. Macdonald D, Cascino T, Schold SJ, Cairncross J. Response criteria for phase II studies of supratentorial malignant glioma. J Clin Oncol. 1990;8:1277-80.

31. Kaplan E, Meier P. Nonparametric estimation from incomplete observations. J Am Stat Assoc. 1958;53:457-81.

32. International Commission on Radiation Units and Measurements. Prescribing, recording, and reporting photon beam therapy. ICRU Report 50. 50. Bethesda, MD; 1993.

33. Lichter A, Sandler H, Robertson J, Lawrence T, Ten Haken R, McShan D, et al. Clinical experience with three-dimensional treatment planning. Semin Radiat Oncol. 1992;2:257-66.

34. Dhermain F, Ducreux D, Bidault F, Bruna A, Parker F, Roujeau T, et al. Use of the functional imaging modalities in radiation therapy treatment planning in patients with glioblastoma. Bull Cancer. 2005;92:333-42.

35. Larson D, Prados M, Lamborn K, Smith V, Sneed P, Chang S, et al. Phase II study of high central dose gamma knife radiosurgery and marimastat in patients with recurrent malignant glioma. Int J Radiat Oncol Biol Phys. 2002;54:1397-404.

36. Lederman G, Arbit E, Odaimi M, Lombardi E, Wrzolek M, Wronski M. Fractionated stereotactic radiosurgery and concurrent taxol in recurrent glioblastoma multiforme: a preliminary report. Int J Radiat Oncol Biol Phys. 1998;40:661-6.

37. Schafer U, Micke O, Schuller P, Schuck A, Willich N. The effect of sequential radiochemotherapy in preirradiated malignant gliomas in a phase II study. J Neurooncol. 2004;67:233-9.

38. Schonekaes K, Mucke R, Panke J, Rama B, Wagner W. Combined radiotherapy and temozolomide in patients with recurrent high grade glioma. Tumori. 2002;88:28-31

39. Laing W, Warrington A. Efficacy and toxicity of fractionated stereotactic radiotherapy in the treatment of recurrent gliomas (phase I/II study). Radiother Oncol. 1993;27:22-9.

40. Hudes R, Corn B, Werner-Wasik M, Andrews D, Rosenstock J, Thoron L, et al. A phase I dose escalation study of hypofractionated stereotactic radiotherapy as salvage therapy for persistent or recurrent malignant glioma. Int J Radiat Oncol Biol Phys. 1999;43:293-9.

41. Vordermark D, Kolbl O, Ruprecht K, Vince G, Bratengeier K, Flentje M. Hypofractionated stereotactic re-irradiation: treatment option in recurrent malignant glioma. BMC Cancer. 2005;5:55.

42. Dhermain F, de Crevoisier R, Parker F, Cioloca C, Kaliski A, Beaudre A, et al. Role of radiotherapy in recurrent gliomas. Bull Cancer. 2004;91:883-9.

43. Flickinger J, Kondziolka D, Pollock B, Maitz A, Lunsford L. Complications from arteriovenous malformation radiosurgery: multivariate analysis and risk modeling. Int J Radiat Oncol Biol Phys. 1997;38:485-90.

44. Cho K, Hall W, Gerbi B, Higgins P, McGuire W, Clark H. Single dose versus fractionated stereotactic radiotherapy for recurrent high-grade gliomas. Int J Radiat Oncol Biol Phys. 1999;45: 1133-41.

45. Schultheiss T, Kun L, Ang K, Stephens L. Radiation response of the central nervous system. Int J Radiat Oncol Biol Phys. 1995:31:1093-112.

46. Shapiro W, Green S, Burger P, Mahaley MJ, Selker R, VanGilder J, et al. Randomized trial of three chemotherapy regimens and two radiotherapy regimens in postoperative treatment of malignant glioma. Brain Tumor Cooperative Group Trial 8001. J Neurosurg. 1989;71:1-9.

47. Enami B, Lyman J, Brown A, Coia L, Goitein M, Munzenrider JE. Tolerance of normal tissue to therapeutic irradiation. Int J Radiat Oncol Biol Phys. 1991;21:109-22.

48. Sheline G, Wara W, Smith V. Therapeutic irradiation and brain injury. Int J Radiat Oncol Biol Phys. 1980;6:1215-28.

49. Flickinger J, Deutsch M, Lunsford L. Repeat megavoltage irradiation of pituitary and suprasellar tumors. Int J Radiat Oncol Biol Phys. 1989;17:171-5. 
50. Flickinger J, Lunsford L, Kondziolka D. Dose prescription and dose-volume effects in radiosurgery. Neurosurg Clin N Am. 1992;3:51-9.

51. Coughlin C, Scott C, Langer C, Coia L, Curran W, Rubin P. Phase II, two-arm RTOG trial (94-11) of bischloroethylnitrosurea plus accelerated hyperfractionated radiotherapy (64.0 or $70.4 \mathrm{~Gy})$ based on tumor volume ( $>20$ or $<$ or $=20 \mathrm{~cm}(2)$, respectively) in the treatment of newly-diagnosed radiosurgery-ineligible glioblastoma multiforme patients. Int J Radiat Oncol Biol Phys. 2000;48:1351-8.

52. Wood J, Green S, Shapiro W. The prognostic importance of tumor size in malignant gliomas: a computed tomographic scan study by the Brain Tumor Cooperative Group. J Clin Oncol. 1988;6:338-43

53. Curran W, Scott C, Weinstein A, Martin L, Nelson J, Phillips T, et al. Survival comparison of radiosurgery-eligible and -ineligible malignant glioma patients treated with hyperfractionated radiation therapy and carmustine: a report of Radiation Therapy Oncology Group 83-02. J Clin Oncol. 1993;11:857-62.

54. Stupp R, van den Bent M, Hegi M. Optimal role of temozolomide in the treatment of malignant gliomas. Curr Neurol Neurosci Rep. 2005;5:198-206.

55. Stupp R, Mason WP, van den Bent MJ, Weller M, Fisher B, Taphoorn MJB, et al. Radiotherapy plus concomitant and adjuvant temozolomide for glioblastoma. N Engl J Med. 2005;352:987-96.

56. Stupp R, Pavlidis N, Jelic S. ESMO minimum clinical recommendations for diagnosis, treatment and follow-up in malignant glioma. Ann Oncol. 2005;16:i64-i65.

57. Douple E, Richmond R. Enhancement of the potentiation of radiotherapy by platinum drugs in a mouse tumor. Int $\mathrm{J}$ Radiat Oncol Biol Phys. 1982;8:501-3.

58. Fu K. Biological basis for the interaction of chemotherapeutic agents and radiation therapy. Cancer. 1985;55:2123-30.
59. Phillips T, Fu K. The interaction of drug and radiation effects on normal tissues. Int J Radiat Oncol Biol Phys. 1978;4:59-64.

60. Douple E, Eaton W, Tulloh M. Skin radiosensitization studies using combined cis-dichlorodiaminneplatinum (II) and radiation. Int J Radiat Oncol Biol Phys. 1979;5:1383-5.

61. Wilkins D, Ng C, Raaphorst G. Cisplatin and low dose rate irradiation in cisplatin resistant and sensitive human glioma cells. Int J Radiat Oncol Biol Phys. 1996;36:105-11.

62. Sheleg S, Korotkevich E, Zhavrid E, Muravskaya G, Smeyanovich A, Shanko Y, et al. Local chemotherapy with cisplatin-depot for glioblastoma multiforme. J Neurooncol. 2002;60:53-9.

63. Thompson S, Davis L, Kornfeld M, Hilgers R, Standefer J. Cisplatin neuropathy, clinical, electrophysiology, morphologic, and toxicologic studies. Cancer. 1984;54:1269-75.

64. Stewart D, Leavens M, Maor M, Feun L, Luna M, Bonura J, et al. Human central nervous system distribution of cisDiamminedichloroplatinum and use as a radiosensitizer in malignant brain tumors. Cancer Res. 1982;42:2474-9.

65. Rich J, Reardon D, Peery T, Dowell JM, Quinn JA, Penne KL, et al. Phase II trial of gefitinib in recurrent glioblastoma. J Clin Oncol. 2004;22:133-42.

66. Fine HA, Figg WD, Jaeckle K, Wen PY, Kyritsis AP, Loeffler JS, et al. Phase II trial of the antiangiogenic agent thalidomide in patients with recurrent high-grade gliomas. J Clin Oncol. 2000;18:708-15.

67. Brem H, Piantadosi S, Burger PC, Walker M, Selker R, Vick NA, et al. Placebo-controlled trial of safety and efficacy of intraoperative controlled delivery by biodegradable polymers of chemotherapy for recurrent gliomas: the polymer-brain tumor treatment group. Lancet. 1995;345:1008-12. 